This item was submitted to Loughborough's Research Repository by the author.

Items in Figshare are protected by copyright, with all rights reserved, unless otherwise indicated.

\title{
Synthesis of Tetracyclic 2,3-Dihydro-1,3-diazepines from a Dinitrodibenzothiophene derivative
}

\author{
PLEASE CITE THE PUBLISHED VERSION
}

https://doi.org/10.1021/acs.joc.8b02029

\section{PUBLISHER}

(c) American Chemical Society

\section{VERSION}

AM (Accepted Manuscript)

\section{PUBLISHER STATEMENT}

This document is the Accepted Manuscript version of a Published Work that appeared in final form in Journal of Organic Chemistry, copyright $\odot$ American Chemical Society after peer review and technical editing by the publisher. To access the final edited and published work see https://pubs.acs.org/doi/10.1021/acs.joc.8b02029.

\section{LICENCE}

CC BY-NC-ND 4.0

\section{REPOSITORY RECORD}

Montanaro, Stephanie, lain A. Wright, Andrei S. Batsanov, and Martin R. Bryce. 2019. "Synthesis of Tetracyclic 2,3-dihydro-1,3-diazepines from a Dinitrodibenzothiophene Derivative". figshare. https://hdl.handle.net/2134/35233. 


\title{
Synthesis of Tetracyclic 2,3-Dihydro-1,3-diazepines from a Dinitro- dibenzothiophene Derivative
}

\author{
Stephanie Montanaro ${ }^{\dagger, \ddagger}$, Iain A. Wright ${ }^{* \ddagger}$, Andrei S. Batsanov ${ }^{\dagger}$, and Martin R. Bryce ${ }^{* \dagger}$ \\ † Department of Chemistry, Durham University, Durham, DH1 3LE, U.K. \\ ‡ Department of Chemistry, Loughborough University, Loughborough, LE11 3TU, U.K.
}

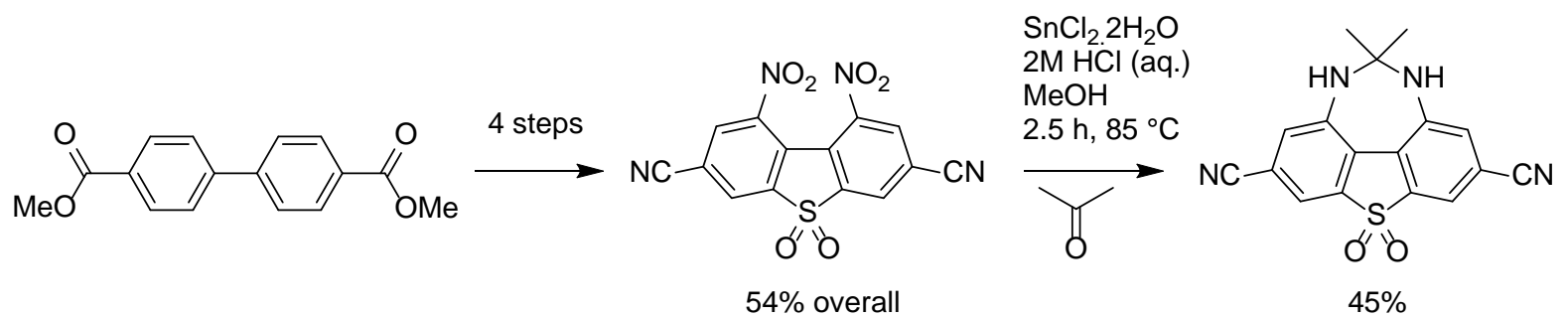

\begin{abstract}
Triply-fused 1,3-diazepine derivatives have been obtained by acidic reduction of rotationally locked and sterically hindered nitro groups in the presence of an aldehyde or ketone. The nitro groups are sited on adjacent rings of a dicyanodibenzothiophene-5,5dioxide which also displays fully reversible two-electron accepting behavior. The synthesis, crystallographically determined molecular structures and aspects of the electronic properties of these new molecules are presented.
\end{abstract}

Developing new routes to underexplored heterocyclic motifs is a fundamental driving force in organic chemistry and is essential to identifying new structures of medicinal or technological value. Diazepines are of major pharmaceutical importance. ${ }^{1-3}$ 1,2- and 1,4-benzodiazepines in particular comprise entire classes of drugs, including the anti-anxiety medications tofisopam (strictly a 2,3-diazepine) and diazepam. ${ }^{4-8}$ 1,3-Diazepines, and the saturated analogues 1,3diazepanes, are less prevalent; however they have been studied as HIV protease inhibitors, ${ }^{9-14}$ as anti-cancer ${ }^{15-20}$ and anti-viral agents, ${ }^{15,21-28}$ and also as $N$-heterocyclic carbene ligands. ${ }^{29,30}$ In comparison with 1,2- and 1,4-diazepines, routes to 1,3-diazepines are less clearly established. Since the last comprehensive survey of their synthesis ${ }^{31}$ only a handful of new synthetic approaches have been reported for monocyclic, ${ }^{32-35}$ singly- $^{36-39}$ or doubly-ringfused 1,3-diazepines. ${ }^{40-49}$

In this work the introduction of sterically hindered nitro groups at the 1- and 9-positions of a dibenzothiophene-5,5-dioxide derivative provides access to a new two-electron accepting molecule, which is a precursor to luminescent four-ring-fused 2,3-dihydro-1,3-diazepines 6-8 
using facile protocols in synthetically viable yields. To our knowledge these molecules represent the first examples of tetracyclic 1,3-diazepine derivatives.

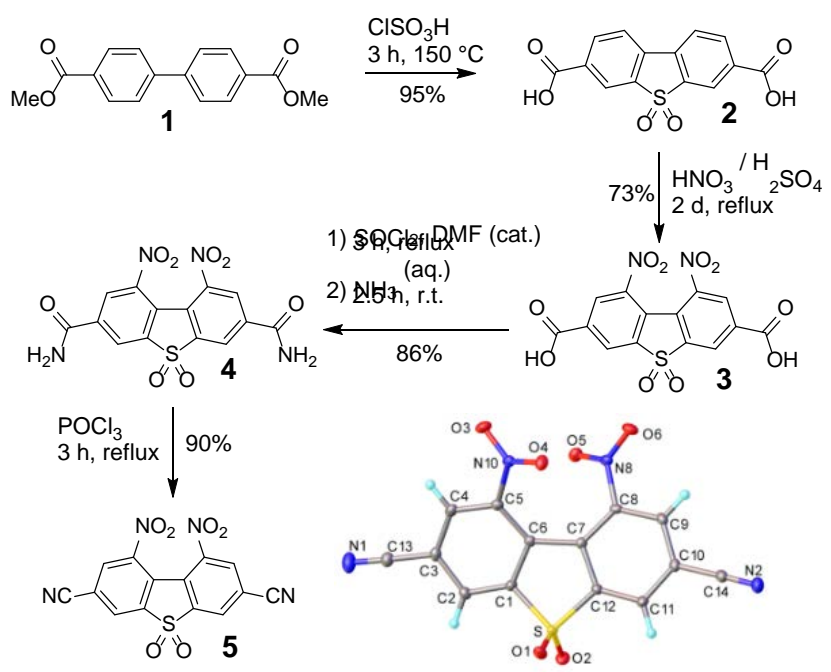

Scheme 1. Synthesis of the new acceptor 5 and its X-ray molecular structure.

The synthesis of the new dibenzothiophene-5,5-dioxide acceptor is shown in Scheme 1. Simultaneous cyclization and acidic hydrolysis of dimethyl biphenyl-4,4'-dicarboxylate $\mathbf{1}$ was achieved in refluxing chlorosulfonic acid according to the procedure of Olkhovik et al to produce the diacid $2 .{ }^{50}$ In the same report, mononitration of $\mathbf{2}$ at the 1-position was performed, therefore, by using the more concentrated fuming nitric acid and extending the reaction time dinitration was achieved to produce 1,9-dinitrodibenzothiophene-5,5-dioxide3,7-dicarboxylic acid 3. A byproduct containing a nitro group in the 2-position was reported for the mononitration; ${ }^{50}$ however, we did not observe this during our dinitration process. Finally, the carboxylic acid groups of $\mathbf{3}$ were easily converted to nitriles using standard procedures. Reaction of 3 with an excess of refluxing $\mathrm{SOCl}_{2}$ and a catalytic amount of $N, N$ dimethylformamide (DMF) gave the presumed diacyl chloride derivative, which was reacted immediately with aqueous ammonia to produce the diamide derivative $\mathbf{4}$, which had low solubility. Compound 4 was then dehydrated with $\mathrm{POCl}_{3}$ to give $\mathbf{5}$. Each step in Scheme 1 is straightforward to perform relying upon simple precipitation and filtration to isolate products. The overall yield is $54 \%$ for the five-step sequence to compound 5 .

Considerable twisting of the aromatic skeleton of $\mathbf{5}$ occurs due to a combination of steric hindrance and repulsive electronic effects between the nitro groups. Relief of this ring-strain should be a useful driving force in exploiting the reactivity of these nitro groups towards producing new heterocycles. Indeed, reduction of the nitro groups of $\mathbf{5}$ in the presence of 
aldehydes or ketones provides convenient access to the brightly colored 2,3-dihydro-1,3diazepines 6-8 featuring alkyl or aromatic substituents at the 2-position, via the diamine $\mathbf{9}$ (Scheme 2).

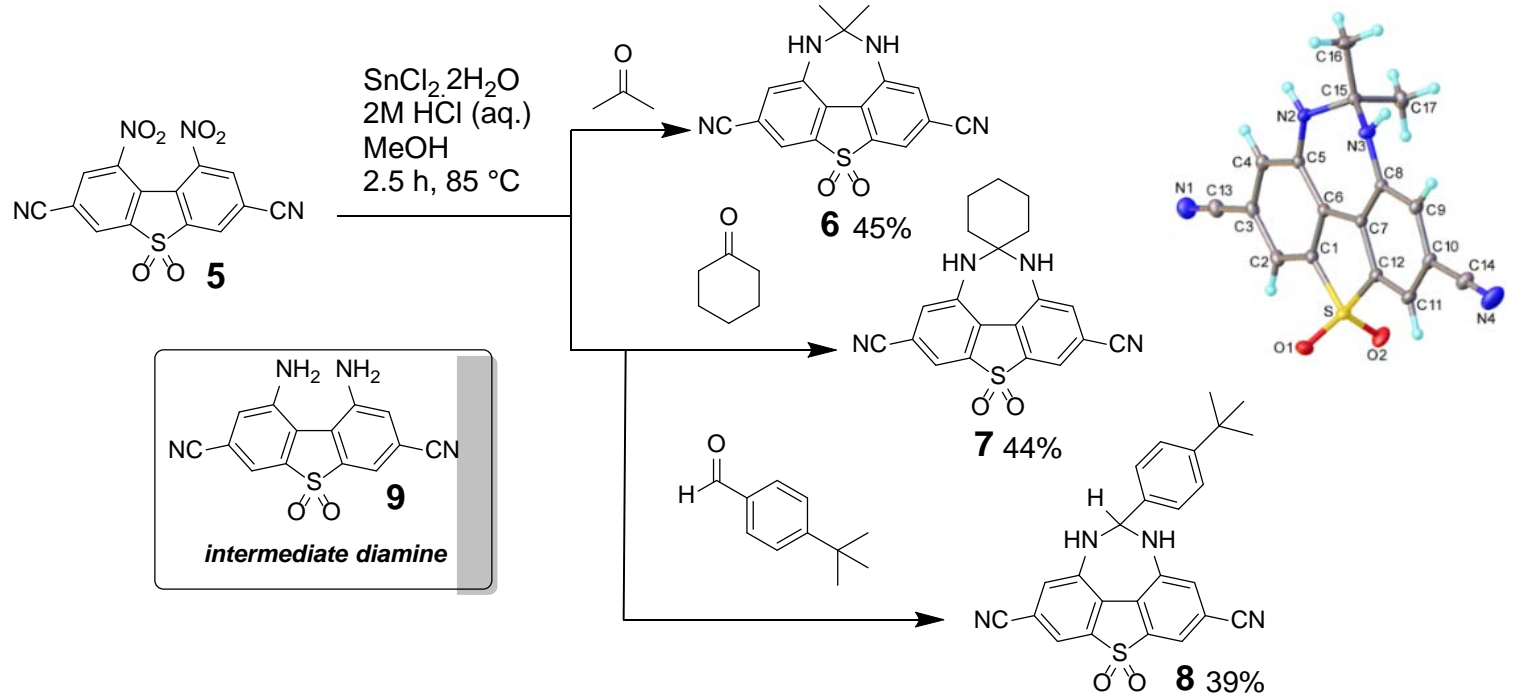

Scheme 2. Synthesis of tetracyclic 1,3-diazepines 6, 7 and 8 from 5 via intermediate diamine $\mathbf{9}$, and the X-ray molecular structure of $\mathbf{6}$.

Acidic reduction of 5 using $\mathrm{SnCl}_{2} 2 \mathrm{H}_{2} \mathrm{O}$ in the presence of acetone provided the $N, N^{\prime}$ isopropylidene-2,3-dihydro-1,3-diazepine derivative $\mathbf{6}$. The modest yield (45\%) is offset by the straightforward practical protocol. To confirm the intermediacy of the diamine $\mathbf{9}$ in this process a separate experiment was performed in which 9 was isolated, albeit in only 14\% yield, and then cyclized in acidic acetone to provide 6 in 78\% yield. The one-pot approach is, therefore, much more expedient than performing the reduction and cyclization sequentially, due to difficulties in isolating the diamine 9. Analogous one-pot reactions using cyclohexanone and 4-tert-butylbenzaldehyde gave 7 and 8, respectively, in 44\% and 39\% yields.

We note that electrochemical reduction of 2,2'-dinitrobiphenyl in the presence of aldehydes and ketones has previously been used to produce 1,3-diazepines. ${ }^{51}$ However, the reaction conditions reported above for converting 9 into 6 did not work with 2,2'dinitrobiphenyl; no diazepine was isolated and the only major product identified was 2,2'diaminobiphenyl. This agrees with a previously reported high yielding, tin-mediated, reduction of this ${ }^{52}$ and related compounds. ${ }^{53,54}$ We are aware of one example of a reductive cyclization of a 2,2'-dinitrobiaryl using $\mathrm{SnCl}_{2}$ and an identical reaction stoichiometry to the 
present work which resulted in trace (5\%) benzo[c]cinnoline formation. ${ }^{55}$ These results indicate that the structurally enforced proximity of the two amino groups in $\mathbf{9}$ is required for efficient reductive cyclization.

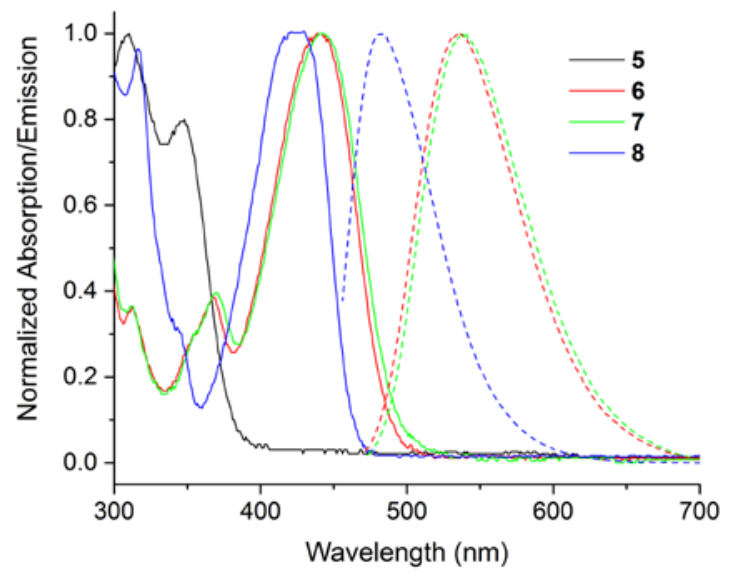

Figure 1. Absorption (solid line) and emission spectra (dashed line) for compounds 5-8 in MeCN solution.

The diazepines 6-8 were brightly colored and emissive in both the solid state and in solution, unlike the precursor $\mathbf{5}$ which is non-emissive. Absorption and emission spectra in acetonitrile are shown in Figure 1 and summarized in Table S1. The absorption and emission in the visible region for $\mathbf{6 - 8}$ is probably due to strong intramolecular charge transfer between the electron rich diazepine and electron poor dibenzothiophene-5,5-dioxide regions. This postulation is strengthened by solvatochromism observed as a blue shift in emission of up to $26 \mathrm{~nm}$ when moving from highly polar acetonitrile $\left(\varepsilon_{r}=37.5\right)$ to less polar chloroform $\left(\varepsilon_{r}=\right.$ 4.81, Figure S1 and Table S1). There is a substantial difference in color between the ketone products 6 and 7 (orange) and aldehyde product 8 (yellow).

The molecular structures of $\mathbf{5}$ (in three different crystal forms) and $\mathbf{6}$ were determined by single-crystal X-ray diffraction (see SI) and, in good agreement, calculated using density functional theory (DFT, B3LYP/6-31G*). Both methods show molecule 5 adopting a twisted conformation of the dibenzothiophene system, in order to widen the short contacts N...N and N...O between adjacent nitro-groups (Table 1), whereas in $\mathbf{6}$ the dibenzothiophene unit is practically planar, $\mathrm{N}(2)$ and $\mathrm{N}(3)$ are coplanar with it and their (post-cyclization) separation is much shorter than in 5, the C6-C7 bond also shortening slightly. The 1,3-diazepine ring of 6 adopts a half-chair conformation with the N2-C15-N3 fragment inclined to the dibenzothiophene plane by $51.5(1)^{\circ}$ (cf. calculated $34.6^{\circ}$ ). The accurate prediction of 
structures 5 and 6 by DFT analysis encouraged us to perform it for 9 whose single crystals could not be obtained. The predicted structure is intermediate between those of $\mathbf{5}$ and $\mathbf{6}$ (Figure S5, Table 1).

Table 1. Experimental and calculated torsion angles $\left(^{\circ}\right)$ and interatomic distances $(\AA)^{a}$

\begin{tabular}{llll}
\hline Molecule & $\mathbf{5}$ & $\mathbf{6}$ & $\mathbf{9}$ \\
\hline C5-C6-C7-C8 / DFT & 18.2 & 0 & 16.3 \\
X-ray & $18.0-23.5$ & 1.2 & - \\
C1-C6-C7-C12 / DFT & 13.1 & 0 & 8.7 \\
X-ray & $12.0-14.4$ & 0.7 & - \\
N2..N3 / DFT & 2.997 & 2.411 & 2.774 \\
X-ray & $2.901(3)-3.001(2)$ & $2.425(2)$ & - \\
N2..O5 / DFT & 2.681 & - & \\
X-ray & $2.587(7)-2.717(2)$ & - & - \\
C6-C7 / DFT & 1.490 & 1.474 & \\
X-ray & $1.486(2)-1.494(4)$ & $1.472(2)$ & - \\
\hline
\end{tabular}

${ }^{a}$ For atom numbering see Schemes 1 and 2.

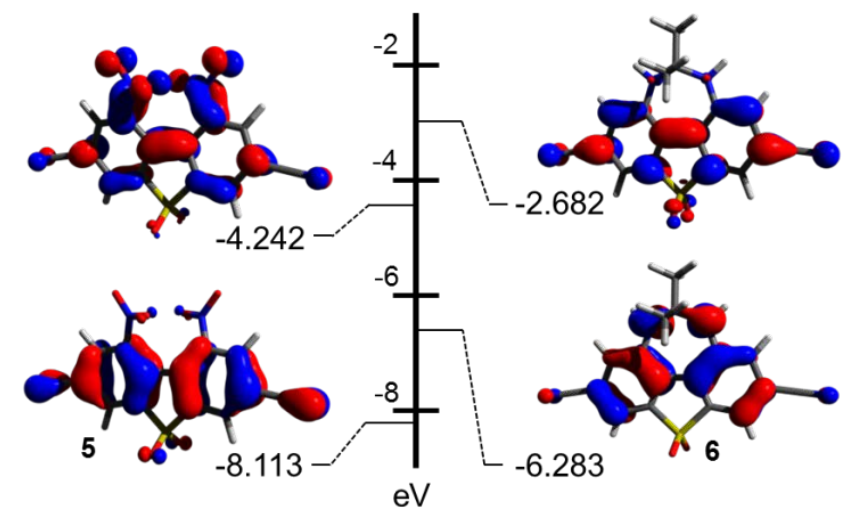

Figure 2. HOMO (lower) and LUMO (upper) contours for $\mathbf{5}$ and $\mathbf{6}$ and their calculated energies.

Molecular orbital distributions for 5 and $\mathbf{6}$ (Figure 2) show a major contribution to the LUMO of 5 from the nitro groups, the nitrogen atoms of which subsequently become HOMO contributors upon reduction and cyclization to $\mathbf{6}$. The results of identical calculations for $\mathbf{9}$ are shown in Figure S6.

\section{Electrochemistry}




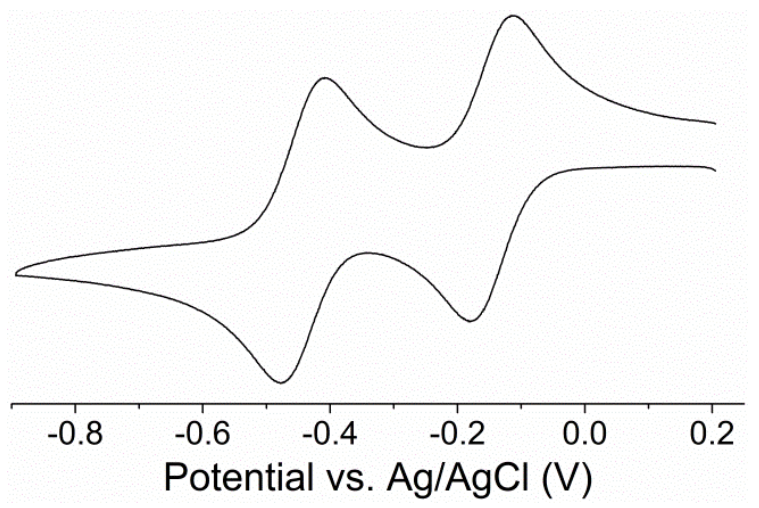

Figure 3. Cyclic voltammetry of 5

An interesting feature of the diazepine precursor compound $\mathbf{5}$ is its ability to accept two electrons as shown in cyclic voltammetry (CV) experiments. The voltammogram in Figure 3 shows two, sequential, single-electron reductions at half wave potentials of -0.15 and $-0.45 \mathrm{~V}$. Both processes are cleanly reversible displaying a linear dependence between peak current and the square root of the scan rate (Figures S8 and S9) and peak separations close to the $59 \mathrm{mV}$ expected for a 1-electron wave. The data are summarized in Table S4 alongside a more detailed discussion of the properties of $\mathbf{5}$ in comparison with some related fluorenone based acceptors. ${ }^{56}$

In conclusion, an efficient synthetic route has been established to an unusual highlyfunctionalized fused-ring 2,3-dihydro-1,3-diazepine system from the key dinitro compound 5 based on a one-pot reduction followed by reaction with aldehyde or ketone functionality. A comparison with 2,2'-dinitrobiphenyl shows that the structurally-enforced proximity of the two amino groups in $\mathbf{9}$ is required for diazepine formation. There is scope to exploit this chemistry in the synthesis of other interesting products. For example, the close proximity of the nitro groups in $\mathbf{5}$ suggests that ring closure to benzo[c]cinnoline type scaffolds may also be feasible using alternative reaction conditions, ${ }^{57-59}$ while other suitably nitrated carbo- and heterocycles such as fluorenes or carbazoles might behave similarly to $\mathbf{5}$, providing further structural diversity for fused-ring 1,3-diazepines.

\section{EXPERIMENTAL}

General methods. All reactions requiring an inert atmosphere were performed under a blanket or argon or nitrogen gas which was dried though a column of phosphorus pentoxide. Anhydrous solvents were dried through an HPLC column on an innovative Technology Inc. solvent purification system. All reactants and reagents were purchased from commercial 
suppliers and used without further purification unless otherwise stated. Column chromatography was carried out using silica gel 60: 40-60 $\mu$ m mesh (Fluorochem). Analytical thin-layer chromatography was performed on precoated aluminium silica gel 60 $\mathrm{F}_{254}$ plates (Merck) which were approximately 2x6 cm in size and visualization was made using ultraviolet light (254/365 nm). NMR spectra were recorded on: Bruker Avance-400 $\left({ }^{1} \mathrm{H}\right.$ NMR (400 MHz), ${ }^{13} \mathrm{C}(101 \mathrm{MHz})$ Varian Inova-500 ( ${ }^{13} \mathrm{C}$ NMR (125MHz) and Varian VNMRS-700 ( $\left.{ }^{1} \mathrm{H}(700 \mathrm{MHz}),{ }^{13} \mathrm{C}(175 \mathrm{MHz})\right)$ NMR spectrometers. Chemical shifts are reported in ppm downfield of tetramethylsilane (TMS) using TMS or the residual solvent as an internal reference. NMR spectra were processed using MestreNova. Multiplicities are reported as singlet (s), doublet (d), triplet (t), and multiplet (m). Melting points were determined in open-ended capillaries using Stuart Scientific SMP3 melting point apparatus at a ramping rate of $1{ }^{\circ} \mathrm{C} / \mathrm{min}$. They are recorded to the nearest $1{ }^{\circ} \mathrm{C}$ and are uncorrected. Mass spectrometry data were generated by Waters Ltd, UK (atmospheric solids analysis probe (ASAP) mass spectrometry). IR spectra were collected on a Perkin-Elmer Spectrum Two IR spectrometer. Elemental analyses were obtained on an Exeter Analytical Inc. CE-440 elemental analyzer. Cyclic voltammetry was recorded using a Princeton Applied Research VersaSTAT 3. Glassy carbon disk, Pt wire and $\mathrm{Ag} / \mathrm{Ag}^{+}\left(\mathrm{AgNO}_{3}\right.$ in acetonitrile) were used as the working, counter and reference electrodes respectively. Measurements were corrected to the ferrocene/ferrocenium redox couple as an internal standard and represented versus $\mathrm{Ag} / \mathrm{AgCl}$ which occurred at $-0.45 \mathrm{~V}$ versus $\mathrm{Fc} / \mathrm{Fc}^{+}$in these conditions. Acetonitrile was used as the solvent with an analyte molarity of ca. $10^{-4} \mathrm{M}$ in the presence of $1 \times 10^{-3} \mathrm{M}(n$ $\left.\mathrm{Bu}_{4} \mathrm{~N}\right)\left(\mathrm{PF}_{6}\right)$ as supporting electrolyte. Solutions were degassed with Ar and experiments run under a blanket of Ar. UV/Vis absorbance spectra were measured using a UV-1800 UV-Vis Spectrophotometer (Shimadzu) and UVProbe version 2.33 software. Emission spectra were recorded on an SPEX Fluoromax luminescence spectrometer using dM300 version 3.12 software. Density function theory (DFT) calculations were performed with ORCA v4.0160 using the B3LYP hybrid functional and 6-31G* basis set. ${ }^{61-63}$ Ground state structural optimizations were performed prior to frontier orbital calculations.

5,5-Dioxo-5H-dibenzo[b,d]thiophene-3,7-dicarboxylic acid (2): ${ }^{50}$ A solution of dimethyl biphenyl-4,4'-dicarboxylate 1 (5.00 g, $19.0 \mathrm{mmol}$ ) in chlorosulfonic acid (20 mL) was heated at reflux for $3 \mathrm{~h}$. The reaction mixture was cooled to room temperature and poured over ice to precipitate the product. The white precipitate was filtered and washed with water $(50 \mathrm{~mL})$, hexane $(40 \mathrm{~mL})$ and diethyl ether $(40 \mathrm{~mL})$. The white powder was recrystallized from 
acetone to afford 2 as a white crystalline solid (5.51 g, 95\%). Mp: > $350{ }^{\circ} \mathrm{C} ;{ }^{1} \mathrm{H}$ NMR (400 MHz, DMSO-d $\left.\mathrm{d}_{6}, \mathrm{ppm}\right) \delta=8.43\left(2 \mathrm{H}, \mathrm{d}, J=7.7 \mathrm{~Hz}, \mathrm{H}_{1 / 9}\right), 8.38$ (2H, d, $\left.J=0.9 \mathrm{~Hz}, \mathrm{H}_{4 / 6}\right), 8.36$ (2H, dd, $\left.J=8.0,1.5 \mathrm{~Hz}, \mathrm{H}_{2 / 8}\right)$.

\section{1,9-Dinitro-5,5-dioxo-5H-dibenzo[b,d]thiophene-3,7-dicarboxylic acid (3): A 1 L two-} necked round bottom flask equipped with a water cooled reflux condenser and a pressure equalizing dropping funnel was charged with 2 (18.0 g, $59.2 \mathrm{mmol})$ and 95\% sulfuric acid (d $=1.83,165 \mathrm{~mL})$ and placed in an ice batch. Fuming 90\% nitric acid $(\mathrm{d}=1.50,250 \mathrm{~mL})$ was added cautiously using to the stirred solution through the dropping funnel while maintaining the temperature between $5-10{ }^{\circ} \mathrm{C}$. The ice bath was swapped for a heating block which was then slowly heated to $130{ }^{\circ} \mathrm{C}$ for $48 \mathrm{~h}$. To minimize corrosive vapors escaping the reaction vessel the top of the reflux condenser was connected by PVC tubing to an empty $500 \mathrm{~mL}$ Dreschel bottle (to avoid the risk of suck back into the reaction vessel) which in turn was connected by another length of PVC tubing the end of which was submerged approximately 2 $\mathrm{cm}$ below the surface of $400 \mathrm{~mL}$ of water in a $1 \mathrm{~L}$ beaker. After heating, the mixture was allowed to cool then poured over ice. The white precipitate that formed was filtered and washed with water $(60 \mathrm{~mL})$ then hexane $(40 \mathrm{~mL})$. The crude product was recrystallized from acetic acid to afford 3 as a white crystalline solid (17.1 g, 73\%). Mp: >350 ${ }^{\circ} \mathrm{C}$; ${ }^{1} \mathrm{H}$ NMR (400 MHz, DMSO-d 6 , ppm) $\delta=8.89$ (2H, d, $\left.J=1.5 \mathrm{~Hz}, \mathrm{H}_{2 / 8}\right), 8.71\left(2 \mathrm{H}, \mathrm{d}, J=1.5 \mathrm{~Hz}, \mathrm{H}_{4 / 6}\right) ;{ }^{13} \mathrm{C}$ NMR (101 MHz, DMSO-d6, ppm) $\delta=163.6,146.3$, 141.0, 137.0, 131.1, 127.1, 123.9; IR ( $\left.v_{\max } / \mathrm{cm}^{-1}\right) 3095(\mathrm{w}), 2523$ (br), 1707 (s, C=O), 1543 and 1359 (s, NO $\left.\mathrm{NO}_{2}\right), 1326$ and 1146 (s, SO $\mathrm{SO}_{2}$ ), 279 (s), 1185 (s), 1172 (s), 744 (s); MS (ASAP) m/z: 395.0 [M + H] ; HRMS (ASAP) m/z: $[\mathrm{M}+\mathrm{H}]^{+}$Calcd for $\mathrm{C}_{14} \mathrm{H}_{7} \mathrm{~N}_{2} \mathrm{O}_{10} \mathrm{~S}$ 394.9816; Found 394.9811 .

1,9-Dinitro-5,5-dioxo-5H-dibenzo[b,d]thiophene-3,7-dicarboxamide (4): A few drops of DMF were added to a suspension of $3(15.0 \mathrm{~g}, 38.0 \mathrm{mmol})$ in thionyl chloride (380 $\mathrm{mL})$ which was then heated to reflux for $3 \mathrm{~h}$ to form a yellow solution. Upon cooling to room temperature the excess thionyl chloride was removed under reduced pressure to afford a pale yellow solid (16.4 g, $38.0 \mathrm{mmol})$. The yellow solid was then suspended in water (20 mL) with stirring before $35 \%$ aqueous ammonia solution $(d=0.88,200 \mathrm{~mL})$ was very carefully added dropwise (CAUTION! gas evolution). The reaction mixture was left to stir at room temperature for $2.5 \mathrm{~h}$ then poured over ice to produce a brown precipitate which was filtered off and washed with diethyl ether $(50 \mathrm{~mL})$ then hexane $(50 \mathrm{~mL})$ to yield $\mathbf{4}$ as a pale brown solid (12.7 g, 86\%). The compound was used without further purification. Mp: $230{ }^{\circ} \mathrm{C}$ (dec.); ${ }^{1} \mathrm{H}$ NMR (400 MHz, DMSO-d $\left.\mathrm{d}_{6}, \mathrm{ppm}\right) \delta=8.96\left(2 \mathrm{H}, \mathrm{d}, J=1.0 \mathrm{~Hz}, \mathrm{H}_{2 / 8}\right), 8.81(2 \mathrm{H}, \mathrm{d}, J=1.0$ 
$\left.\mathrm{Hz}, \mathrm{H}_{4 / 6}\right), 8.61$ (2H, s, -NH), $8.12(2 \mathrm{H}, \mathrm{s},-\mathrm{NH}) ;{ }^{13} \mathrm{C}$ NMR (101 MHz, DMSO-d 6 , ppm) $\delta=$ 163.3, 146.2, 140.7, 139.6 , 129.9, 125.4, 122.9; IR ( $\left.v_{\max } / \mathrm{cm}^{-1}\right) 3083$ (br), 2924 (w), 1693 (s, $\mathrm{C}=\mathrm{O}), 1616$ (m, amide-H) 1541 and 1352 (s, NO ), 1314 and 1145 (s, SO ), 1386 (m), 1192 (m); MS (ASAP) m/z: $393.0[\mathrm{M}+\mathrm{H}]^{+}$; HRMS (ASAP) m/z: $[\mathrm{M}+\mathrm{H}]^{+}$Calcd for $\mathrm{C}_{14} \mathrm{H}_{9} \mathrm{~N}_{4} \mathrm{O}_{8} \mathrm{~S}$ 393.0136; Found 393.0135.

3,7-Dicyano-1,9-dinitro-5,5-dioxo-5H-dibenzo[b,d]thiophene (5): A solution of 4 (1.60 g, $4.08 \mathrm{mmol}$ ) in phosphorus oxychloride $(40 \mathrm{~mL})$ was heated to reflux for $3 \mathrm{~h}$. The resulting dark orange solution was cooled to room temperature and quenched slowly with warm water. The orange precipitate was filtered and washed with water $(50 \mathrm{~mL})$ and hexane $(30 \mathrm{~mL})$. The crude product was recrystallized from acetonitrile and water to afford $\mathbf{5}$ as pale yellow crystals (1.30 g, 90\%). Mp: $250{ }^{\circ} \mathrm{C}$ (dec.); Elemental Anal. Calcd for $\mathrm{C}_{14} \mathrm{H}_{4} \mathrm{~N}_{4} \mathrm{O}_{6} \mathrm{~S}$ : C 47.20, H 1.13 N 15.73, Found: C 46.84, H 1.12, N 15.70; ${ }^{1} \mathrm{H}$ NMR (400 MHz, acetone-d 6 , ppm) $\delta=$ 9.08 (2H, d, $\left.J=1.5 \mathrm{~Hz}, \mathrm{H}_{2 / 8}\right), 9.02\left(2 \mathrm{H}, \mathrm{d}, J=1.5 \mathrm{~Hz}, \mathrm{H}_{4 / 6}\right) ;{ }^{13} \mathrm{C}$ NMR (101 MHz, acetone-d 6 , ppm) $\delta=147.9,142.8,135.4,131.6,125.5,119.0,115.8$; IR $\left(v_{\max } / \mathrm{cm}^{-1}\right) 3074(\mathrm{w}), 2242$ $(\mathrm{C} \equiv \mathrm{N}, \mathrm{w}), 1547$ and $1352\left(\mathrm{NO}_{2}, \mathrm{~s}\right), 1495(\mathrm{~m}), 1330$ and $1161\left(\mathrm{SO}_{2}, \mathrm{~s}\right), 1227(\mathrm{~m}), 1188(\mathrm{~m})$, 778 (m), 737 (s), 694 (s), 575 (m), 544 (s), 467 (s). Despite repeated attempts using a range of techniques, this molecule was not observed by mass spectrometry. Single crystals for X-ray analysis were grown from both ethyl acetate/hexane and $\mathrm{THF} / \mathrm{MeOH} / \mathrm{H}_{2} \mathrm{O}$ solutions.

\section{$N, N^{\prime}$-isopropylidene-1,9-diamino-3,7-dicyano-5,5-dioxo-5H-dibenzo[b,d]thiophene (6):}

To a stirred solution of $\mathrm{SnCl}_{2} .2 \mathrm{H}_{2} \mathrm{O}(3.00 \mathrm{~g}, 13.4 \mathrm{mmol})$ in a mixture of methanol $(8.50 \mathrm{~mL})$ and aqueous $\mathrm{HCl}(2 \mathrm{M}, 8.5 \mathrm{~mL})$, acetone (1.00 mL, $13.6 \mathrm{mmol}, 16 \mathrm{eq}$ ) ) and 5 (0.30 g, 0.84 mmol) were added sequentially. The mixture was then heated to $85^{\circ} \mathrm{C}$ for $2.5 \mathrm{~h}$. The mixture was cooled to room temperature and poured into aqueous $\mathrm{HCl}(2 \mathrm{M}, 34 \mathrm{~mL})$. An orange precipitate immediately formed which was filtered and washed with hexane (30 mL). It was then purified by silica column chromatography (eluent: 30:70 hexane: ethyl acetate (v/v)) to afford 6 as an orange powder (128 mg, 45\%). Mp: $350{ }^{\circ} \mathrm{C}$ (dec.); ${ }^{1} \mathrm{H}$ NMR (400 MHz, acetone- $\left.\mathrm{d}_{6}, \mathrm{ppm}\right) \delta=7.64\left(2 \mathrm{H}, \mathrm{d}, J=1.3 \mathrm{~Hz}, \mathrm{H}_{4 / 6}\right), 7.44\left(2 \mathrm{H}, \mathrm{d}, J=1.3 \mathrm{~Hz}, \mathrm{H}_{2 / 8}\right), 6.98(2 \mathrm{H}, \mathrm{s}$, -NH-), 1.63 (6H, s, $\left.-\mathrm{CH}_{3}\right)$; ${ }^{13} \mathrm{C}$ NMR (101 MHz, acetone- $\left.\mathrm{d}_{6}, \mathrm{ppm}\right) \delta=146.1,140.2,126.9$, 119.1, 118.0, 114.6, 114.3, 67.2, 28.4; IR $\left(v_{\max } / \mathrm{cm}^{-1}\right) 3331(\mathrm{~N}-\mathrm{H}, \mathrm{m}), 2917(\mathrm{w}), 2233(\mathrm{C} \equiv \mathrm{N}$, m), 1740 (m), 1606 (m), 1526 (m), 1457 (m), 1367 (m), 1308 and 1150 (SO, $\mathrm{s}), 1278$ (m), 1028 (m), 876 (m), 713 (m), 624 (m), 545(s); MS (ASAP) m/z: 337.1 [M + H] ; HRMS (ASAP) m/z: [M + H] $]^{+}$Calcd. for $\mathrm{C}_{17} \mathrm{H}_{13} \mathrm{~N}_{4} \mathrm{O}_{2} \mathrm{~S}$ 337.0754; Found 337.0753. 


\section{$N, N$-cyclohexylidene-1,9-diamino-3,7-dicyano-5,5-dioxo-5H-dibenzo[b, $d]$ thiophene (7):}

To a stirred solution of $\mathrm{SnCl}_{2} .2 \mathrm{H}_{2} \mathrm{O}(5.07 \mathrm{~g}, 22.5 \mathrm{mmol})$ in a mixture of methanol $(14 \mathrm{~mL})$ and aqueous $\mathrm{HCl}(2 \mathrm{M}, 14 \mathrm{~mL})$, cyclohexanone $(0.73 \mathrm{~mL}, 7.0 \mathrm{mmol})$ and 5 (0.50 g, 1.40 mmol) were added. The mixture was then heated to $85{ }^{\circ} \mathrm{C}$ for $2.5 \mathrm{~h}$. The mixture was cooled to room temperature and poured into aqueous $\mathrm{HCl}(2 \mathrm{M}, 56 \mathrm{~mL})$. An orange precipitate immediately formed which was filtered and washed with hexane (30 mL). It was then purified by silica column chromatography (eluent: 40:60 hexane: ethyl acetate (v/v)) to afford 7 as small orange crystals (230 mg, 44\%). Mp: $300{ }^{\circ} \mathrm{C}$ (dec.); ${ }^{1} \mathrm{H}$ NMR (400 MHz, acetone$\left.\mathrm{d}_{6}, \mathrm{ppm}\right) \delta=7.64\left(2 \mathrm{H}, \mathrm{d}, J=1.3 \mathrm{~Hz}, \mathrm{H}_{4 / 6}\right), 7.59$ (2H, d, $\left.J=1.3 \mathrm{~Hz}, \mathrm{H}_{2 / 8}\right), 6.84(2 \mathrm{H} \mathrm{s},-\mathrm{NH}-)$, $1.92-1.84$ (4H, m, $\left.-\mathrm{CH}_{2}-\right), 1.69-1.49$ (6H, m, $\left.-\mathrm{CH}_{2}-\right)$; ${ }^{13} \mathrm{C}$ NMR (101 MHz, acetone- $\mathrm{d}_{6}$, ppm) $\delta=145.5,140.1$, 127.2, 119.6, 118.0, 114.7, 114.3, 68.8, 36.1, 25.8, 22.4; IR $\left(v_{\max } / \mathrm{cm}^{-1}\right.$ ) 3401 (m), 3356 (m), $3321(\mathrm{~N}-\mathrm{H}, \mathrm{m}), 3076$ (w), 2941 (w), $2241(\mathrm{C} \equiv \mathrm{N}, \mathrm{m}), 1606$ (m), 1517 (s), 1305 and 1150 (SO2, s) 852 (m), 708 (m), 620 (m); MS (ASAP) m/z: $377.1[\mathrm{M}+\mathrm{H}]^{+}$; HRMS (ASAP) m/z: [M + H] $]^{+}$Calcd. for $\mathrm{C}_{20} \mathrm{H}_{17} \mathrm{~N}_{4} \mathrm{O}_{2} \mathrm{~S}$ 377.1067; Found: 377.1067.

\section{$N, N^{\prime}$-(4-tert-butylbenzylidene)-1,9-diamino-3,7-dicyano-5,5-dioxo-5H-}

dibenzo[b,d]thiophene (8): To a stirred solution of $\mathrm{SnCl}_{2} .2 \mathrm{H}_{2} \mathrm{O}(2.02 \mathrm{~g}, 8.99 \mathrm{mmol})$ in a mixture of methanol (6 mL) and aqueous $\mathrm{HCl}(2 \mathrm{M}, 6 \mathrm{~mL})$, 4-tert-butylbenzaldehyde (0.50 $\mathrm{mL}, 2.81 \mathrm{mmol})$ and 5 (0.20 g, $0.56 \mathrm{mmol})$ were added. The mixture was then heated to 85 ${ }^{\circ} \mathrm{C}$ for $2.5 \mathrm{~h}$. The mixture was cooled to room temperature and poured into aqueous $\mathrm{HCl}(2$ M, $25 \mathrm{~mL})$. The organics were then extracted into ethyl acetate (3 x $15 \mathrm{~mL})$ and washed with water ( 2 x $25 \mathrm{~mL}$ ). The organic fractions were dried over magnesium sulfate and the ethyl acetate removed under vacuum to afford an oil. The oil was dissolved in dichloromethane (30 $\mathrm{mL})$ and hexane $(20 \mathrm{~mL})$ was added. The solvent was reduced in volume (ca. $10 \mathrm{~mL})$ to precipitate the crude product as a yellow powder. It was then purified by silica column chromatography (eluent: 70:30 hexane: ethyl acetate (v/v)) to afford $\mathbf{8}$ as a yellow crystalline powder (92 mg, 39\%). Mp: $300{ }^{\circ} \mathrm{C}$ (dec.); ${ }^{1} \mathrm{H}$ NMR (400 MHz, acetone-d 6 , ppm) $\delta=7.69$ $\left(2 \mathrm{H}, \mathrm{d}, J=1.4 \mathrm{~Hz}, \mathrm{H}_{4 / 6}\right), 7.65\left(2 \mathrm{H}, \mathrm{d}, J=1.4 \mathrm{~Hz}, \mathrm{H}_{2 / 8}\right), 7.58-7.48\left(4 \mathrm{H}, \mathrm{m}, \mathrm{H}^{4-t-\mathrm{BuC}_{6} \mathrm{H}_{4}}\right), 7.17$ (2H, s, -NH-), 5.34 (1H, s, -CH-), 1.36 (9H, s, $\left.-\mathrm{CH}_{3}\right) ;{ }^{13} \mathrm{C}$ NMR (101 MHz, acetone- $\mathrm{d}_{6}$, ppm) $\delta=153.2$, 148.5, 140.7, 136.7, 128.3, 126.9, 126.4, 118.9, 118.0, 115.2, 113.8, 71.2, 35.3, 31.6; IR $\left(v_{\max } / \mathrm{cm}^{-1}\right) 3355(\mathrm{~N}-\mathrm{H}, \mathrm{w}), 3063(\mathrm{w}), 2956(\mathrm{w}), 2233(\mathrm{C} \equiv \mathrm{N}, \mathrm{m}), 1605(\mathrm{~m})$, 1505 (s), 1468 (s), 1305 and 1145 (SO 2, s), 1268 (m), 1202 (m), 886 (m), 836 (m), 707 (m), 621 (m); MS (ASAP) m/z: $441.1[\mathrm{M}+\mathrm{H}]^{+}$; HRMS (ASAP) m/z: [M + H] ${ }^{+}$Calcd. for $\mathrm{C}_{25} \mathrm{H}_{21} \mathrm{~N}_{4} \mathrm{O}_{2} \mathrm{~S}$ 441.1380; Found: 441.1374. 
1,9-diamino-3,7-dicyano-5,5-dioxo-5H-dibenzo[b,d]thiophene (9): To a stirred solution of $\mathrm{SnCl}_{2} .2 \mathrm{H}_{2} \mathrm{O}(5.07 \mathrm{~g}, 22.5 \mathrm{mmol})$ in a mixture of ethanol $(14 \mathrm{~mL})$ and aqueous $\mathrm{HCl}(2 \mathrm{M}, 14$ $\mathrm{mL}$ ), 5 (0.50 g, $1.40 \mathrm{mmol}$ ) was added. The mixture was heated to $85^{\circ} \mathrm{C}$ for $2.5 \mathrm{~h}$ then cooled to room temperature and poured into aqueous $\mathrm{HCl}(2 \mathrm{M}, 56 \mathrm{~mL})$. An orange precipitate immediately formed which was filtered and washed with hexane $(30 \mathrm{~mL})$. The product was purified by silica column chromatography (eluent: started 30:70 hexane: ethyl acetate (v/v) gradually increased polarity to 100\% ethyl acetate) to afford $\mathbf{9}$ as a light brown powder (60 mg, 14\%). Mp: $300{ }^{\circ} \mathrm{C}$ (dec.); ${ }^{1} \mathrm{H}$ NMR (400 MHz, DMSO-D 6 , ppm) $\delta=7.79$ (2H, d, $\left.J=1.5 \mathrm{~Hz}, \mathrm{H}_{4 / 6}\right), 7.52\left(2 \mathrm{H}, \mathrm{d}, J=1.5 \mathrm{~Hz}, \mathrm{H}_{2 / 8}\right), 6.60\left(4 \mathrm{H}, \mathrm{s},-\mathrm{NH}_{2}\right) ;{ }^{13} \mathrm{C} \mathrm{NMR}(101$ MHz, DMSO- D 6 , ppm) $\delta=145.0,139.1,126.5,118.1,117.6,112.9,112.6$; IR $\left(v_{\max } / \mathrm{cm}^{-1}\right)$ 3451 and $3360(\mathrm{~N}-\mathrm{H}, \mathrm{m}), 3243(\mathrm{w}), 3070(\mathrm{w}), 2226(\mathrm{C} \equiv \mathrm{N}, \mathrm{s}), 1632$ and $1598\left(\mathrm{NH}_{2}, \mathrm{~s}\right), 1543$ (m), 1467 (m), 1430 (m), 1346 (m), 1299 and 1143 (SO, s), 1253 (m), 1194 (m), 881 (m), 617 (m). MS (ASAP) m/z: $297.0[\mathrm{M}+\mathrm{H}]^{+}$; HRMS (ASAP) m/z: [M + H] Calcd. for $\mathrm{C}_{14} \mathrm{H}_{9} \mathrm{~N}_{4} \mathrm{O}_{2} \mathrm{~S}$ 297.0441; Found: 297.0437.

\section{ASSOCIATED CONTENT}

\section{Supporting Information}

${ }^{1} \mathrm{H}$ and ${ }^{13} \mathrm{C}$ NMR spectra for all new compounds, absorption and emission spectra, computational details for $\mathbf{5 , 6}$, and $\mathbf{9}$ and computational results for $\mathbf{9}$, electrochemical properties of 1 and further crystallographic details (PDF).

CIF files for 5, 5•1/2THF and 6.

Crystallographic data uploaded to Cambridge Crystallographic Database: CCDC 18500711850073.

\section{AUTHOR INFORMATION}

\section{Corresponding Authors}

*E-mails and ORCID: m.r.bryce@durham.ac.uk; ORCID 0000-0003-2097-7823 (M.R.B.). i.a.wright@lboro.ac.uk; ORCID 0000-0002-0142-2809 (I.A.W.).

\section{Notes}

The authors declare no competing financial interest. 


\section{ACKNOWLEDGEMENTS}

M.R.B. and I.A.W. thank EPRSC for funding (Grant No. EP/K016164/1). I.A.W. thanks Loughborough University and the Royal Society of Chemistry Research Fund (Grant No. RF18-5353) for funding.

\section{References}

(1) Schütz, H. Benzodiazepines; Springer Berlin Heidelberg: Berlin, Heidelberg, 1982.

(2) Schuetz, H. Benzodiazepines II. A Handbook.; Springer Berlin Heidelberg: Berlin, Heidelberg, 1989.

(3) Hosmane, R. S. Ring-Expanded ('fat') Purines and Their Nucleoside/nucleotide Analogues as Broad-Spectrum Therapeutics. In Progress in Heterocyclic Chemistry; 2009; Vol. 21, pp 35-68.

(4) Smith, S. G.; Sanchez, R.; Zhou, M. M. Privileged Diazepine Compounds and Their Emergence as Bromodomain Inhibitors. Chem. Biol. 2014, 21 (5), 573-583.

(5) Meagher, T. P.; Murugan, R. 1,2-Diazepines. In Comprehensive Heterocyclic Chemistry III; Elsevier, 2008; pp 143-160.

(6) Snieckus, V.; Streith, J. 1,2-Diazepines: A New Vista in Heterocyclic Chemistry. Acc. Chem. Res. 1981, 14 (11), 348-355.

(7) Kaur, N.; Kishore, D. Synthetic Strategies Applicable in the Synthesis of Privileged Scaffold: 1,4-Benzodiazepine. Synth. Commun. 2014, 44 (10), 1375-1413.

(8) Meanwell, N. A.; Walker, M. A. 1,4-Diazepines. In Comprehensive Heterocyclic Chemistry III; Elsevier, 2008; pp 183-235.

(9) Hodge, C. N.; Lam, P. Y. S.; Eyermann, C. J.; Jadhav, P. K.; Ru, Y.; Fernandez, C. H.; De Lucca, G. V.; Chang, C. H.; Kaltenbach, R. F.; Holler, E. R.; et al. Calculated and Experimental Low-Energy Conformations of Cyclic Urea HIV Protease Inhibitors. $J$. Am. Chem. Soc. 1998, 120 (19), 4570-4581.

(10) Jadhav, P. K.; Ala, P.; Woerner, F. J.; Chang, C. H.; Garber, S. S.; Anton, E. D.; Bacheler, L. T. Cyclic Urea Amides: Hiv-1 Protease Inhibitors with Low Nanomolar 
Potency against Both Wild Type and Protease Inhibitor Resistant Mutants of HIV. J. Med. Chem. 1997, 40 (2), 181-191.

(11) Han, W.; Pelletier, J. C.; Hodge, C. N. Tricylic Ureas: A New Class of HIV-1 Protease Inhibitors. Bioorganic Med. Chem. Lett. 1998, 8 (24), 3615-3620.

(12) Debnath, A. K. Three-Dimensional Quantitative Structure-Activity Relationship Study on Cyclic Urea Derivatives as HIV-1 Protease Inhibitors: Application of Comparative Molecular Field Analysis. J. Med. Chem. 1999, 42 (2), 249-259.

(13) Lam, P. Y. S.; Ru, Y.; Jadhav, P. K.; Aldrich, P. E.; DeLucca, G. V.; Eyermann, C. J.; Chang, C.-H.; Emmett, G.; Holler, E. R.; Daneker, W. F.; et al. Cyclic HIV Protease Inhibitors: Synthesis, Conformational Analysis, P2/P2' Structure-Activity Relationship, and Molecular Recognition of Cyclic Ureas. J. Med. Chem. 1996, 39 (18), 3514-3525.

(14) Lam, P. Y. S.; Jadhav, P. K.; Eyermann, C. J.; Hodge, C. N.; Ru, Y.; Bacheler, L. T.; Meek, J. L.; Otto, M. J.; Rayner, M. M.; Wong, Y. N.; et al. Rational Design of Potent, Bioavailable, Nonpeptide Cyclic Ureas as HIV Protease Inhibitors. Science 1994, 263, 380-384.

(15) Wittine, K.; Poljak, K.; Kovac, M.; Makuc, D.; Plavec, J.; Balzarini, J.; Martinovic, T.; Pavelic, S. K.; Pavelic, K.; Mintas, M. The Novel [4,5-e][1,3]Diazepine-4,8-Dione and Acyclic Carbamoyl Imino-Ureido Derivatives of Imidazole: Synthesis, Anti-Viral and Anti-Tumor Activity Evaluations. Molecules 2013, 18 (11), 13385-13397.

(16) Xie, M.; Lapidus, R. G.; Sadowska, M.; Edelman, M. J.; Hosmane, R. S. Synthesis, Anticancer Activity, and SAR Analyses of Compounds Containing the 5:7-Fused 4,6,8-triaminoimidazo[4,5-e][1,3]diazepine Ring System. Bioorganic Med. Chem. 2016, 24 (12), 2595-2602.

(17) Kondaskar, A.; Kondaskar, S.; Kumar, R.; Fishbein, J. C.; Muvarak, N.; Lapidus, R. G.; Sadowska, M.; Edelman, M. J.; Bol, G. M.; Vesuna, F.; et al. Novel, Broad Spectrum Anticancer Agents Containing the Tricyclic 5:7:5-Fused Diimidazodiazepine Ring System. ACS Med. Chem. Lett. 2011, 2 (3), 252-256.

(18) Kondaskar, A.; Kondaskar, S.; Fishbein, J. C.; Carter-Cooper, B. A.; Lapidus, R. G.; Sadowska, M.; Edelman, M. J.; Hosmane, R. S. Structure-Based Drug Design and 
Potent Anti-Cancer Activity of Tricyclic 5:7:5-Fused diimidazo[4,5-d:4',5'f][1,3]diazepines. Bioorganic Med. Chem. 2013, 21 (3), 618-631.

(19) Bellet, V.; Lichon, L.; Arama, D. P.; Gallud, A.; Lisowski, V.; Maillard, L. T.; Garcia, M.; Martinez, J.; Masurier, N. Imidazopyridine-Fused [1,3]-Diazepinones Part 2: Structure-Activity Relationships and Antiproliferative Activity against Melanoma Cells. Eur. J. Med. Chem. 2017, 125, 1225-1234.

(20) Gallud, A.; Vaillant, O.; Maillard, L. T.; Arama, D. P.; Dubois, J.; Maynadier, M.; Lisowski, V.; Garcia, M.; Martinez, J.; Masurier, N. Imidazopyridine-Fused [1,3]Diazepinones: Synthesis and Antiproliferative Activity. Eur. J. Med. Chem. 2014, 75, 382-390.

(21) Zhang, N.; Chen, H. M.; Sood, R.; Kalicharran, K.; Fattom, A. I.; Naso, R. B.; Barnard, D. L.; Sidwell, R. W.; Hosmane, R. S. In Vitro Inhibition of the Measles Virus by Novel Ring-Expanded ('fat') Nucleoside Analogues Containing the imidazo[4,5-e][1,3]diazepine Ring System. Bioorganic Med. Chem. Lett. 2002, 12 (23), 3391-3394.

(22) Zhang, P.; Zhang, N.; Buckwold, V. E.; Hosmane, R. S. Chemical and Biological Effects of Substitution of the 2-Position of Ring-Expanded ('fat') Nucleosides Containing the imidazo[4,5-e][1,3]diazepine-4,8-Dione Ring System: The Role of Electronic and Steric Factors on Glycosidic Bond Stability and Anti-HCV a. Bioorganic Med. Chem. 2007, 15 (14), 4933-4945.

(23) Zhang, P.; Zhang, N.; Korba, B. E.; Hosmane, R. S. Structure-Activity Relationship Studies on Anti-HCV Activity of Ring-Expanded ('fat') Nucleobase Analogues Containing the imidazo[4,5-e][1,3]diazepine-4,8-Dione Ring System. Bioorganic Med. Chem. Lett. 2007, 17 (8), 2225-2228.

(24) Zhang, P.; Zhang, N.; Korba, B. E.; Hosmane, R. S. Synthesis and in Vitro AntiHepatitis B and C Virus Activities of Ring-Expanded ('fat') Nucleobase Analogues Containing the imidazo[4,5-e][1,3] Diazepine-4,8-Dione Ring System. Bioorganic Med. Chem. Lett. 2005, 15 (24), 5397-5401.

(25) Bretner, M.; Beckett, D.; Sood, R. K.; Baldisseri, D. M.; Hosmane, R. S. Substrate/inhibition Studies of Bacteriophage T7 RNA Polymerase with the 5'- 
triphosphate Derivative of a Ring-Expanded ('fat') Nucleoside Possessing Potent Antiviral and Anticancer Activities. Bioorganic Med. Chem. 1999, 7 (12), 2931-2936.

(26) Yedavalli, V. S. R. K.; Zhang, N.; Cai, H.; Zhang, P.; Starost, M. F.; Hosmane, R. S.; Jeang, K. T. Ring Expanded Nucleoside Analogues Inhibit RNA Helicase and Intracellular Human Immunodeficiency Virus Type 1 Replication. J. Med. Chem. 2008, 51 (16), 5043-5051.

(27) Zhang, N.; Chen, H. M.; Koch, V.; Schmitz, H.; Minczuk, M.; Stepien, P.; Fattom, A. I.; Naso, R. B.; Kalicharran, K.; Borowski, P.; et al. Potent Inhibition of NTPase/Helicase of the West Nile Virus by Ring-Expanded (“Fat”) Nucleoside Analogues. J. Med. Chem. 2003, 46 (22), 4776-4789.

(28) Zhang, N.; Chen, H. M.; Koch, V.; Schmitz, H.; Liao, C. L.; Bretner, M.; Bhadti, V. S.; Fattom, A. I.; Naso, R. B.; Hosmane, R. S.; et al. Ring-Expanded ("fat”) Nucleoside and Nucleotide Analogues Exhibit Potent in Vitro Activity against Flaviviridae NTPases/helicases, Including Those of the West Nile Virus, Hepatitis C Virus, and Japanese Encephalitis Virus. J. Med. Chem. 2003, 46 (19), 4149-4164.

(29) Scarborough, C. C.; Popp, B. V.; Guzei, I. A.; Stahl, S. S. Development of 7Membered N-Heterocyclic Carbene Ligands for Transition Metals. J. Organomet. Chem. 2005, 690 (24-25), 6143-6155.

(30) Scarborough, C. C.; Guzei, I. A.; Stahl, S. S. Synthesis and Isolation of a Stable, Axially-Chiral Seven-Membered N-Heterocyclic Carbene. Dalton Trans. 2009, No. 13, 2284-2286.

(31) De Borggraeve, W. M.; Van den Bogaert, A. M. 1,3-Diazepines. In Comprehensive Heterocyclic Chemistry III; Elsevier, 2008; pp 161-182.

(32) Darko, A. K.; Curran, F. C.; Copin, C.; McElwee-White, L. Carbonylation of Functionalized Diamine Diols to Cyclic Ureas: Application to Derivatives of DMP 450. Tetrahedron 2011, 67 (22), 3976-3983.

(33) Fesenko, A. A.; Shutalev, A. D. Nucleophile-Mediated Ring Expansion of 4Chloromethyl- and 4-Mesyloxymethyl-5-Tosyl-1,2,3,4-Tetrahydropyrimidin-2-Ones to 6-Tosyl-2,3,4,5-Tetrahydro-1H-1,3-Diazepin-2-Ones: Effect of the Leaving Group and the Substituent at C6. Tetrahedron 2011, 67 (36), 6876-6882. 
(34) Fesenko, A. A.; Shutalev, A. D. 2,3-Dihydro-1H-1,3-Diazepin-2-Ones: Synthesis and Novel Rearrangements into Pyrrole Derivatives. Tetrahedron Lett. 2014, 55 (8), 14161420.

(35) McCreanor, N. G.; Stanton, S.; Bower, J. F. Capture-Collapse Heterocyclization: 1,3Diazepanes by C-N Reductive Elimination from Rhodacyclopentanones. J. Am. Chem. Soc. 2016, 138 (36), 11465-11468.

(36) Livadiotou, D.; Tsoleridis, C. A.; Stephanidou-Stephanatou, J. A Versatile, Unexpected, One-Pot Regioselective Synthesis of a New Class of 1,3-

Diazepinoindolones by Reaction of Pyranoindolones with Monosubstituted Ureas. Synthesis 2009, No. 15, 2579-2583.

(37) Arama, D. P.; Lisowski, V.; Scarlata, E.; Fulcrand, P.; Maillard, L. T.; Martinez, J.; Masurier, N. An Efficient Synthesis of Pyrido-Imidazodiazepinediones. Tetrahedron Lett. 2013, 54 (11), 1364-1367.

(38) Ozer, M. S.; Koza, G.; Sahin, E.; Balci, M. Furo- and Thieno-Fused 1,3-Diazepine4,6-Diones. Tetrahedron Lett. 2013, 54 (48), 6553-6556.

(39) Zheng, Y.; Chi, Y.; Bao, M.; Qiu, L.; Xu, X. Gold-Catalyzed Tandem Dual Heterocyclization of Enynones with 1,3,5-Triazines: Bicyclic Furan Synthesis and Mechanistic Insights. J. Org. Chem. 2017, 82 (4), 2129-2135.

(40) Yan, L.; Che, X.; Bai, X.; Pei, Y. Syntheses of Novel diaryl[d,f][1,3]diazepines via One-Pot Suzuki Coupling Followed by Direct Ring Closure with Carboxylic Acids. Mol. Divers. 2012, 16 (3), 489-501.

(41) Tomar, M.; Lucas, N. T.; Müllen, K.; Jacob, J. Facile Synthesis and Coupling of 3,9Dibromo-6-Aryl-5H-dibenzo[d,f][1,3] Diazepine Derivatives. Tetrahedron Lett. 2013, 54 (44), 5883-5885.

(42) Kumar, S.; Pratap, R.; Kumar, A.; Kumar, B.; Tandon, V. K.; Ram, V. J. Synthesis of Dibenzo[d,f]diazepinones and Alkenylindolinones through Ring Transformation of 2H-Pyran-2-One-3-Carbonitriles by Indolin-2-Ones. Tetrahedron 2013, 69 (24), 48574865.

(43) Wezeman, T.; Hu, Y.; McMurtrie, J.; Bräse, S.; Masters, K. S. Synthesis of Non- 
Symmetrical and Atropisomeric Dibenzo[1,3]diazepines: Pd/CPhos-Catalysed Direct Arylation of Bis-Aryl Aminals. Aust. J. Chem. 2015, 68 (12), 1859-1865.

(44) Cubbage, K. L.; Orr-Ewing, A. J.; Booker-Milburn, K. I. First Higher-Order Photocycloaddition to a $\mathrm{C}=\mathrm{N}$ Bond: 1,3-Diazepines from Maleimides. Angew. Chemie - Int. Ed. 2009, 48 (14), 2514-2517.

(45) Zaki, M. E. A.; Paula Bettencourt, A.; Fernandes, F. M.; Fernanda Proença, M. Synthesis and Electrochemical Evaluation of Substituted imidazo[4,5-d]pyrrolo[3,2f][1,3] Diazepine Scaffolds. Tetrahedron 2012, 68 (24), 4628-4634.

(46) Masurier, N.; Aruta, R.; Gaumet, V.; Denoyelle, S.; Moreau, E.; Lisowski, V.; Martinez, J.; Maillard, L. T. Selective C-Acylation of 2-aminoimidazo[1,2- a ]Pyridine: Application to the Synthesis of Imidazopyridine-Fused [1,3]diazepinones. $J$. Org. Chem. 2012, 77 (7), 3679-3685.

(47) Lebedyeva, I. O.; Povstyanoy, V. M.; Ryabitskii, A. B.; Panasyuk, O.; Ivahnenko, E.; Lozova, V. P.; Markevich, I.; Allakhverdova, S.; Povstyanoy, M. V. Theophyllinylpyrimidine Scaffolds Undergo Intramolecular Cyclization Reactions to Form 1,3-Diazepines and Imidazopurines. Eur. J. Org. Chem. 2013, No. 21, 45944606.

(48) Wang, X.; Tang, H.; Feng, H.; Li, Y.; Yang, Y.; Zhou, B. Access to Six- and SevenMembered 1,7-Fused Indolines via Rh(III)-Catalyzed Redox-Neutral C7-Selective CH Functionalization of Indolines with Alkynes and Alkenes. J. Org. Chem. 2015, 80 (12), 6238-6249.

(49) Gumbau-Brisa, R.; Hayward, J. J.; Wallis, J. D.; Rawson, J. M.; Pilkington, M. Structural Insights into the Coordination Chemistry and Reactivity of a 3,3'-Bis-Imine2,2'-Bipyridine Ligand. CrystEngComm 2016, 18 (11), 1892-1903.

(50) Olkhovik, V. K.; Vasilevskii, D. A.; Pap, A. A.; Kalechyts, G. V.; Matveienko, Y. V.; Baran, A. G.; Halinouski, N. A.; Petushok, V. G. Synthesis of New Polyconjugated Molecules with Biphenyl, Dibenzothiophene, Carbazole and Phenanthrene Units. ARKIVOC (Gainesville, FL, U.S.) 2008, No. 9, 69-93.

(51) Hazell, R. G.; Iversen, P. E.; Lehmann, M. S. 5,7-Dihydroxy-6,6-Dimethyl-6,7Dihydrodibenzo[ D , F ][1,3]diazepine. Acta Crystallogr. Sect. B Struct. Crystallogr. 
Cryst. Chem. 1978, 34 (11), 3458-3460.

(52) Jiang, J.; Chen, X.; Wang, J.; Hui, Y.; Liu, X.; Lin, L.; Feng, X. Chiral Biphenylamide Derivative: An Efficient Organocatalyst for the Enantioselective Synthesis of $\alpha$ Hydroxy Phosphonates. Org. Biomol. Chem. 2009, 7 (21), 4355-4357.

(53) Wisser, F. M.; Eckhardt, K.; Wisser, D.; Böhlmann, W.; Grothe, J.; Brunner, E.; Kaskel, S. Tailoring Pore Structure and Properties of Functionalized Porous Polymers by Cyclotrimerization. Macromolecules 2014, 47 (13), 4210-4216.

(54) Kundu, P. K.; Lerner, A.; Kučanda, K.; Leitus, G.; Klajn, R. Cyclic Kinetics during Thermal Equilibration of an Axially Chiral Bis-Spiropyran. J. Am. Chem. Soc. 2014, 136 (32), 11276-11279.

(55) Racané, L.; Čičak, H.; Mihalić, Z.; Karminski-Zamola, G.; Tralić-Kulenović, V. New Pentacyclic Ring Systems: Intramolecular Cyclization of O,o'-Disubstituted Bibenzothiazoles. Tetrahedron 2011, 67 (15), 2760-2767.

(56) Perepichka, I. F.; Kuz’mina, L. G.; Perepichka, D. F.; Bryce, M. R.; Goldenberg, L. M.; Popov, A. F.; Howard, J. A. K. Electron Acceptors of the Fluorene Series. 7. 1 2,7Dicyano-4,5-Dinitro-9-X-Fluorenes: Synthesis, Cyclic Voltammetry, Charge Transfer Complexation with N -Propylcarbazole in Solution, and X-Ray Crystal Structures of Two Tetrathiafulvalene Complexes. J. Org. Chem. 1998, 63 (19), 6484-6493.

(57) Bjørsvik, H. R.; González, R. R.; Liguori, L. Investigations of a Novel Process to the Framework of Benzo[c]cinnoline. J. Org. Chem. 2004, 69 (22), 7720-7727.

(58) Sakai, N.; Asama, S.; Anai, S.; Konakahara, T. One-Pot Preparation of Azobenzenes from Nitrobenzenes by the Combination of an Indium-Catalyzed Reductive Coupling and a Subsequent Oxidation. Tetrahedron 2014, 70 (11), 2027-2033.

(59) Elumalai, V.; Bjørsvik, H. R. A Concise Synthesis to Benzo[c]cinnolines via 2,2'Dinitro-1,1'-Biphenyls Attained from a Novel Tailored Suzuki Cross-Coupling. ChemistrySelect 2017, 2 (29), 9387-9390.

(60) Neese, F. The ORCA Program System. Wiley Interdiscip. Rev. Comput. Mol. Sci. 2012, 2 (1), 73-78.

(61) Hehre, W. J.; Ditchfield, K.; Pople, J. A. Self-Consistent Molecular Orbital Methods. 
XII. Further Extensions of Gaussian-Type Basis Sets for Use in Molecular Orbital Studies of Organic Molecules. J. Chem. Phys. 1972, 56 (5), 2257-2261.

(62) Dill, J. D.; Pople, J. A. Self-Consistent Molecular Orbital Methods. XV. Extended Gaussian-Type Basis Sets for Lithium, Beryllium, and Boron. J. Chem. Phys. 1975, 62 (7), 2921-2923.

(63) Francl, M. M.; Pietro, W. J.; Hehre, W. J.; Binkley, J. S.; Gordon, M. S.; DeFrees, D. J.; Pople, J. A. Self-Consistent Molecular Orbital Methods. XXIII. A PolarizationType Basis Set for Second-Row Elements. J. Chem. Phys. 1982, 77 (7), 3654-3665. 